Published in final edited form as:

Semin Oncol. 2009 December ; 36(6): 524. doi:10.1053/j.seminoncol.2009.10.004.

\title{
Estrogen Receptor Signaling in Lung Cancer
}

\author{
Jill M. Siegfried, Ph.D. [Professor], \\ Department of Pharmacology and Chemical Biology, University of Pittsburgh, Pittsburgh, PA \\ Pamela A. Hershberger, Ph.D. [Research Assistant Professor], and \\ Department of Pharmacology and Chemical Biology, University of Pittsburgh, Pittsburgh, PA \\ Laura P. Stabile, Ph.D. [Research Assistant Professor] \\ Department of Pharmacology and Chemical Biology, University of Pittsburgh, Pittsburgh, PA
}

\begin{abstract}
Lung cancer has long been thought of as a cancer that mainly affects men, but over the past several decades, because of the high increase in tobacco use by women, there has been a corresponding dramatic increase in lung cancer among women. Since 1998, lung cancer deaths in women have surpassed those caused by breast cancer in the United States. Annual lung cancer deaths among women in the US also currently surpass those caused by breast, ovarian, and cervical cancers combined. Women are more likely than men to be diagnosed with adenocarcinoma and small-cell carcinoma of the lung compared to squamous cell carcinoma, and never smokers diagnosed with lung cancer are almost three times more likely to be female than male. These observations in the population, coupled to the findings that both estrogen receptors and aromatase, the enzyme that synthesizes $17 \beta$-estradiol, are expressed by lung tumors, suggest a role for female steroid hormones in control of lung cancer growth. Pre-clinical data and clinical data are increasingly emerging to support this concept, and to suggest that a local production of estrogen and expression of ERs occurs in lung tumors that rise in men as well as women. An additional protein that recognizes $17 \beta$-estradiol with high affinity, GPR30, is also expressed in lung tumors at high levels and may be responsible for some of the proliferation signals induced by estrogen.
\end{abstract}

\section{Introduction}

Although there are conflicting data on whether or not tobacco exposure is significantly more carcinogenic to women as the same dose is to men, a number of observations about sex differences in lung cancer are well-accepted. The proportional occurrence of histologic lung carcinoma subtypes differs significantly $(\mathrm{p}<0.0001)$ between men and women $(1,2)$. In men, squamous cell carcinoma is the most common sub-type. In women, adenocarcinoma is the most common histologic subtype (representing over $44 \%$ of all lung tumors), while squamous cell carcinoma makes up only about $21 \%(1,2)$. The extent of DNA damage elicited by tobacco exposure after correcting for dose has also been found in several studies to be higher in the lungs and tumors of women compared to men $(3,4)$, and this has been attributed to a decreased

\section{(C) 2009 Elsevier Inc. All rights reserved.}

Send Correspondence to: Jill M. Siegfried, Ph.D., University of Pittsburgh Cancer Institute, 5117 Centre Ave., Hillman Cancer Center, Research Pavilion 2.18, Pittsburgh PA 15213 Telephone: 412-623-7769 Telefax: 412-623-7768 siegfriedjm@upmc.edu.

Publisher's Disclaimer: This is a PDF file of an unedited manuscript that has been accepted for publication. As a service to our customers we are providing this early version of the manuscript. The manuscript will undergo copyediting, typesetting, and review of the resulting proof before it is published in its final citable form. Please note that during the production process errors may be discovered which could affect the content, and all legal disclaimers that apply to the journal pertain.

From The University of Pittsburgh P50 CA090440 Specialized Program of Research Excellence (SPORE) in Lung Cancer 
DNA repair capacity in women (5). Induction of cytochrome P450 enzymes that activate tobacco carcinogens by $\beta$-estradiol has also been documented (3-5). In a recent study, Fu et $a l$. found significantly more women were diagnosed with lung cancer at an age younger than 50 , when they are presumably largely pre-menopausal, than were men younger than 50 (6). Never smokers diagnosed with lung cancer are much more likely to be female than male (7), and in general, women diagnosed with lung cancer have smoked less than men diagnosed with the disease. In a recent analysis of several large prospective cohorts, Wakelee et al. found that the underlying risk for lung cancer in women who never smoked was over 2 times that of men who never smoked (8). These observations suggest some preference for female-associated pathways in lung cancer development.

\section{Estrogen and Lung Cancer Survival}

Although it is well-established that on average women with advanced lung cancer live longer than men, recent work suggests this effect is confined to older, post-menopausal women. Premenopausal women in general present with more advanced lung cancer with less differentiation, a sign of more aggressive biology. Women over the age of 60 showed a distinct survival advantage over both men and younger women; the difference compared to younger women could be due to higher levels of circulating estrogen in the under 50 population (9). Men in contrast did not show an age effect in survival.

Hormone replacement therapy (HRT) has been examined in relation to lung cancer survival. Ganti et al. have reported a significant association between both a younger median age at lung cancer diagnosis and a shorter median survival time in women who used HRT around the time of diagnosis compared to those who did not (10). The Women's Health Initiative also recently reported a strong adverse effect on survival after a lung cancer diagnosis in women who took hormone replacement therapy containing both $\beta$-estradiol and a progesterone (11). In the WHI randomizd trial, more than 16,000 post-menopausal women received either placebo or daily HRT (containing estrogen plus medroxyprogesterone acetate) for over five years. Smoking history and age, two factors that influence lung cancer diagnosis and survival, were balanced between the two study arms. There was a trend toward more lung cancer diagnoses in the HRT group compared to placebo, which did not reach statistical significance. However, the HRT group experienced a significantly greater likelihood of dying from lung cancer (46\% mortality in the HRT arm versus $27 \%$ in the placebo arm). These observations strongly suggest that HRT provides a tumor growth advantage in lung cancer, as it does in breast cancer.

In contrast, some reports suggest that HRT use prior to lung cancer diagnosis could actually protect women from developing lung cancer, especially if they smoked (12). An inverse relationship was observed between HRT use and NSCLC risk in postmenopausal women with lung tumors that were ER-positive, but not ER-negative (13). These data suggest that there are different effects on the balance between cell differentiation and cell proliferation in response to estrogen in normal or preneoplastic lung epithelium compared to malignant epithelium. Because lung tumors are also known to produce aromatase (see below), it is possible that in normal lung, exogenous hormone use reduced local estrogen production by negative feedback regulation of aromatase.

\section{Function of Estrogen Outside the Reproductive Tract}

Steroid hormone pathways have been effectively targeted in breast and prostate cancer, where hormone-dependent growth is well understood. However, steroid hormone receptors such as the ER are found in many tissues outside the reproductive tract, such as the heart and blood vessels (14). Estrogens are also known to have biological effects in non-reproductive tumors, such as renal cancer (15). Steroid receptors are able to signal independently of steroid ligands; the best-characterized effect in this regard is through activation of steroid receptors by 
phosphorylation (16). Thus, steroid hormone receptors could be biologically active through both steroid-induced signalling and steroid-independent signalling. As discussed below, estrogen receptor (ER) signaling pathways that are proliferative have been found in a number of studies in non-small cell lung cancer (NSCLC). Progesterone receptor (PR) may be active as a differentiation-inducing pathway in lung cancer as well, which could potentially protect against cancer progression (17).

\section{Estrogen Receptor Subtypes}

Estrogen receptors (ERs) are members of the nuclear steroid receptor superfamily. Two forms of the ER have been identified, ER $\alpha$ and ER $\beta$, that are the products of two separate genes. Both $\mathrm{ER} \alpha$ and $\mathrm{ER} \beta$ contain functional domains involved in their nuclear signaling including a sequence called AF-1 near the amino terminus that acts as a ligand-independent transcriptional activation domain; a DNA binding domain located centrally in the protein; and a domain in the carboxy-terminus that contains the ligand binding domain. Also contained in the carboxyterminus is another transcriptional activation function, termed AF-2, that carries out liganddependent activation of the receptor (18). ER $\alpha$ has been known for decades, while a second high affinity estrogen receptor, ER $\beta$, was discovered by two different laboratories simultaneouly in the mid-1990's $(19,20)$. Although the affinity for estrogen of the ER $\beta$ protein is similar to that of $\mathrm{ER} \alpha$, the AF-1 domain of $\mathrm{ER} \beta$ is trucated compared to ER $\alpha$ and also is less active at inducing transcriptional activation (21). The two ERs display different tissue distributions, with ER $\alpha$ highest in breast, ovarian, and endometrial tissues and ER $\beta$ highest in ovaries and lung $(19,22)$. When bound by an agonist such as $17 \beta$-estradiol, a conformational change in the AF-2 domain is induced, creating an interaction surface for ER coactivator proteins $(23,24)$, which causes chromatin unwinding and production of an active gene transcription complex. Activation of an ERE by $17 \beta$-etradiol and other selective estrogen response modifiers (SERMs) has been found in lung tumor cells $(25,26)$.

\section{Estrogen Receptors in Normal Lung}

Genetic manipulation has been used to demonstrate which tissues outside the reproductive tract contain biologically functional ERs. A transgenic mouse in which an ERE-luciferase reporter construct was expressed in 26 different tissues was produced, and estrogen-responsive tissues were identified in ovarectomized female mice treated with $17 \beta$-estradiol or vehicle. The lungs displayed 15 -fold induction of luciferase reporter gene activity that was $17 \beta$-estradiol dependent, a greater effect than that observed in known hormone-responsive tissues such as bone, uterus and mammary gland (27). In another ERE-luciferase reporter gene mouse model, Lemmen et al. showed that $17 \beta$-estradiol also significantly induced luciferase activity in the lungs of male and female mice (28), suggesting the lungs of both sexes are estrogen responsive. Targeted inactivation of ER $\beta$, but not ER $\alpha$ was shown to result in lung abnormalities. The number of alveoli is significantly decreased in lungs from female ER $\beta-/-$ mice at 3 months of age compared to WT controls, and ER $\beta-/$ - females also display reduced surfactant (29). Both male and female ER $\beta$-deficient mice exhibit significant lung dysfunction (abnormal extracellular matrix deposition and alveolar collapse) by 5 months, causing systemic hypoxia (30). The observation that this phenotype occurs in both adult female and male mice suggests either that effects of lung development through ER $\beta$ occur in a ligand-independent manner, or that estrogens act via a local autocrine mechanim in the lungs of both sexes.

\section{Estrogen Receptors in Lung Cancer}

There are inconsistent reports of the presence of ERs in lung tumors, although early studies probed for the presence of the classical ER $\alpha$ protein only. With the development of antibodies that can differentiate between $\operatorname{ER} \alpha$ and $\operatorname{ER} \beta$, it is now apparent that $\operatorname{ER} \beta$ is expressed in the majority of human NSCLC cell lines, and is also present in primary tissues of human non-small 
cell lung carcinomas (NSCLCs) from both men and women (25,31-34). The role of ER $\alpha$ in lung cancer is less clear. Antibodies that are used clinically to detect ER $\alpha$ in breast tumors show little or no reactivity in lung tumors. Using an antibody that recognizes the ER $\alpha$ carboxyterminus, staining was mainly found in the cytoplasm and cell membrane in immunohistochemical studies (25). Based on immunoblot analysis, the proteins detected by this antibody consist mainly of smaller, variant proteins, which was confirmed by the presence of many alternatively spliced mRNAs, with little full-length mRNA (25). This non-nuclear $\mathrm{ER} \alpha$ pool presumably is comprised of variant isoforms that lacks the amino-terminus because the proteins are not detected by antibodies that recognize the ER $\alpha$ amino-terminus.

In contrast, ER $\beta$ was found localized to both the nucleus and the cytoplasm, and was comprised of mainly full-length protein in addition to some variants (25). In a number of studies, nuclear localization of ER $\beta$ was observed in lung tumors; between $45-69 \%$ of lung cancer cases were positive (31-34), while ER $\alpha$ was rarely detected. There is little consensus on whether ER $\beta$ expression is a factor in survival. Some studies have suggested a protective effect of nuclear expression (32-34), which may only be significant in men (33). These results are opposite of what has been demonstrated for ER status and prognosis of breast cancer patients $(35,36)$. It is possible the presence of nuclear ER $\beta$ confers a hormone dependence for growth, rather than dependence on other more aggressive oncogenic pathways, leading to comparatively better survival. However, lung tumors with ER $\beta$ expression are still lethal. The specificity of some ER $\beta$ antibodies used in early studies has been disputed, and early studies also did not consider the cytoplasmic ER compartment, which is involved in non-genomic signaling.

\section{Genomic and non-genomic estrogen signaling in NSCLC cells}

The classical model for $17 \beta$-estradiol regulation of gene expression predicts that transcription of estrogen-responsive genes is increased when ligand-bound ERs translocate to DNA and bind EREs in the promoters of these genes. We have transfected NSCLC cells expressing endogenous ERs with an ERE-tk-luciferase reporter gene. Luciferase reporter gene activity, which serves as a measure of ER-mediated transcription, was quantified after 24 hours. Physiologic levels of $17 \beta$-estradiol resulted in a 2-fold activation of gene reporter activity, which could be blocked by the ER down-regulator fulvestrant $(25,26)$. The genomic activation in NSCLC cell lines could be induced by ligands that are specific for ER $\beta$, while ligands specific for ER $\alpha$ showed no activity (26). In addition, only an ER $\beta$ ligand could increase NSCLC tumor growth in a xenograft model (26).

Estrogen is also known to rapidly activate non-genomic signaling pathways in other systems, leading to increases in second messengers such as cAMP, calcium, and activation of PI3K and MAPK. This rapid signaling leads to changes in protein structure/function and gene transcription and is necesary for full responses to estrogen. For example, inhibition of PI3K or MAPK with pharmacologic agents prevents the $17 \beta$-estradiol-dependent proliferation of endothelial cells (14). Whether the estrogen binding protein at the plasma membrane is identical to ER $\alpha$ or ER $\beta$ is in dispute, and alternative estrogen receptors such as the G-protein coupled receptor GPR30 have been detected (37). Pharmacological inhibitors for GPR30 have been made, which will aid in understanding the relative importance of this protein (37). It is possible that both a classical ER and GPR30 are involved in lung cancer responses to estrogens.

A number of studies have found that $17 \beta$-estradiol initiates membrane signaling in NSCLC cells, as evidenced by rapid phosphorylation of p42/p44 MAPK and/or Akt $(26,38,39,40)$. Plasma membrane fractions from NSCLC cells contain 17ß-estradiol binding activity, and isolated caveolae from NSCLC cells contain proteins that react with ER-specific antibodies (38). These data support the hypothesis that at least a part of the ER pool is present at the plasma membrane and triggers membrane signaling in NSCLC cells. 


\section{Interactions with the epidermal growth factor receptor signalling pathway}

Non-genomic ER signaling may also interact with other membrane growth factor pathways, such as the epidermal growth factor receptor (EGFR/HER-1). The EGFR/HER family of tyrosine kinase receptors are known to be involved in NSCLC growth, protection from apoptosis, and angiogenesis. An interaction between the ER and EGFR has been demonstrated, in which estrogen can rapidly activate the EGFR in lung cancer cell lines through release of EGFR ligands at the cell surface (39). The combination of fulvestrant and gefitinib, an EGFR tyrosine kinase inhibitor, in NSCLC can maximally inhibit cell proliferation and induce apoptosis in vitro and in vivo (39). The EGFR tyrosine kinase inhibitor erlotinib also gave superior anti-tumor activity in NSCLC tumor xenografts when used in combination with fulvestrant (41). Membrane ERs were also found to be co-localized with EGFR in lung tumors (38). Ligand-independent ER non-genomic signaling may also occur, via EGFR downstream mediators that directly phosphorylate ER at specific serine residues (16). These serines were phosphorylated in over $80 \%$ of ER positive lung tumors examined (41). It is possible EGFR and ER pathways act as alternate signaling mechanisms in NSCLC, because EGFR protein expression was down-regulated in response to estrogen and up-regulated in response to fulvestrant in NSCLC cell lines. This suggests that the EGFR pathway is activated when estrogen is depleted (39). Conversely, ER $\beta$ protein expression was down-regulated in response to EGF and up-regulated in response to gefitinib (39). This provides a rationale for dual targeting of these pathways.

A phase I clinical trial using drugs that target EGFR and ER was performed to assess the toxicity of combined treatment of gefitinib with fulvestrant in 22 post-menopausal women (42). These two targeted agents in combination were found to be safe and to have anti-tumor activity in female patients with stage IIIB/V NSCLC. Presence of a high percentage of cells within the tumors with nuclear ER $\beta$ immunostaining was correlated with improved patient survival. Phase II trials examining the combination of erlotinib with fulvestrant are also underway (43).

Combination therapy may increase the duration of response in patients whose tumors harbour an EGFR mutation as well as an improved response rate in patients whose tumors are EGFR wild type.

\section{Localization of ERs to mitochondria}

Estrogens are known to increase mitochondrial function, and this effect has been hypothesized to lead to greater longevity in women compared to men. ER has been found in the mitochondria of breast cancer cells (44). Mechanistic studies examining effects of $17 \beta$-estradiol on the mitochondria has recently shown that nuclear transcription of Nuclear Respiratory Factor-1 (NRF-1) is increased by 17 $\beta$-estradiol in breast cancer and lung cancer cells (45), that ER $\beta$ changes mitochondrial sensitivity to oxidative stress (46), and that mitochondrial DNA EREs respond to estrogen to regulate gene expression in mitochondria (47-49). NRF-1 encodes a transcription factor needed to promote mitochondrial DNA transcription and replication (50), and NRF-1 mRNA expression is estrogen responsive in both breast and lung cancer (45). The NRF-1 target gene, TFAM as well as mitochondrial genes regulated by TFAM were also positivly regulated by $17 \beta$-estradiol treatment. Stimulation of mitochondrial function/ biogenesis through nuclear genomic regulation of the NRF-1 promoter by ERs may be a key function of estrogen.

ER $\beta$ has been shown to localize to mitochondria in many cell types such as neurons, skeletal muscle cells, and human lens cells, pointing to a general role for this ER sub-type in regulating function of mitochondria (51-54). Hippocampal HT-22 cells with engineered loss of ER $\beta$ are refractory to cell death induced by mitochondrial stressors and showed reduced superoxide production after oxidative insult (46). This suggests that ER $\beta$ promotes mitochondrial vulnerability, suggesting that an increase in estrogen signaling through ER $\beta$ in the lung would 
promote lung cancer development or progression by reducing cellular susceptibility to oxidative insults. Conversely, it is predicted that lung cancer cells would become more susceptible to stress- inducing agents under conditions of estrogen deficiency. Mitochondrial localization of ER $\beta$ in NSCLC cell lines has been reported (45), and studies are required to determine whether ER $\beta$ is expressed in the mitochondria of primary lung cancer cells and what role is has in oxidative processes.

\section{Preclinical studies of estrogens on growth of NSCLC}

Several preclinical mouse models have been used to study the role of estrogen in lung cancer. In mice in which lung adenocarcinomas were induced by $K$-ras activation and $p 53$ deletion, $17 \beta$-estradiol promoted tumor progression. Administration of $\beta$-estradiol at physiologic levels doubled the number of tumors observed in whole lung mounts and this difference was similar in both males and ovariectomized females (55). In lung cancer cell lines in culture, 17 $\beta$ estradiol significantly increased cell growth in vitro and in tumor xenografts, increased gene expression of several ERE-responsive genes, and increased VEGF secretion. Extent of p44/ p42 mitogen activated protein kinase (MAPK) was also increased $(16,38,39,56,57)$. These proliferative and survival responses to $17 \beta$-estradiol may be responsible for the poorer clinical outcomes observed in NSCLC patients who have high endogenous or exogenous estrogen levels. The ER antagonist fulvestrant significantly inhibited the 17ß-estradiol induced growth of NSCLC cell lines in culture and in tumor xenografts (39), providing strong rationale for the evaluation anti-estrogens in lung cancer therapy.

\section{Aromatase in Lung Cancer}

Recent reports demonstrate that lung cancer cells can produce their own estrogen (58). The aromatase enzyme, a cytochrome $\mathrm{P} 450$ protein, catalyzes the conversion of the androgens androstenedione and testosterone to estrone and estradiol, respectively, and is expressed in the lung $(59,60)$. Aromatase protein was detected in NSCLC cell lines and primary tumor tissue and was shown to be functional, based on detection of $\beta$-estradiol release over time (61). A large decrease in size of lung tumor xenografts treated with anastrozole was also observed (61). Aromatase inhibitor therapy in lung cancer is further supported by Coombes and colleagues, who reported a decreased incidence of primary lung cancer in breast cancer patients treated long-term with the potent aromatase inhibitor exemestane after tamoxifen therapy (4 cases) compared with continued tamoxifen treatment (12 cases) (62). In addition, a recent report showed that aromatase was a protective marker of survival in women over age 65 with early stage lung cancer (63). This finding suggests the effect of local estrogen production is highest in patients where circulating estrogens are low because the ovaries have ceased functioning. Whether aromatase could be important in the survival of men with lung cancer is not known.

\section{Implications for Lung Cancer Therapy}

Given the preclinical data supporting the ability of estrogen ligands to increase gene expression and stimulate the growth of NSCLC cells, there is a strong rationale to evaluate anti-tumor activity of estrogen down-modulators in lung cancer. The available strategies for targeting estrogen signaling clincially include antagonists of ER function such as tamoxifen, downregulation of ER function through agents such as fulvestrant and reduction of estrogen levels through aromatase inhibitors, such as the reversible non-steroidal agents letrozole and anastrozole and the irreversible steroidal inactivator exemestane $(64,65)$. Tamoxifen has a partial agonist effects in certain tissues, such as endometrium, and is known to act as an agonist for some ER $\beta$ functions, such as stimulating AP-1-mediated transcription (66). Tamoxifen has been shown by our group to increase lung tumor xenograft growth (unpublished observations) and is not an appropriate choice of therapy for NSCLC. Additionally, results from the 
Tamoxifen Breast Cancer Prevention trial as part of the National Surgical Adjuvant Breast and Bowel Project did not show any decreased risk of lung cancer (67). Seventeen tumors of the lung, trachea, and bronchus were reported among the placebo group and 20 in the women who had received tamoxifen therapy. Although not statistically significant, these results suggest that tamoxifen could have some agonistic effects in the lung. Findings that lung tumors express high amounts of the enzyme aromatase and contain measureable intra-tumoral $17 \beta$-estradiol and its metabolites (68), as well as the recent observation of increased lung cancer deaths in women on HRT therapy (11), point to aromatase inhibitors as a viable potential therapeutic option. In addition, a recent case report described a post-menopausal woman with lung cancer whose tumor enlarged during a course of HRT (69). It is possible that reducing estrogenic signaling will have activity on its own, and also increase the efficacy of chemotherapy and other targeted therapies.

Understanding the biology and signaling of estrogen in lung cancer will be of benefit to both women and men with this disease. Lung tumors from both male and female patients express ERs and aromatase, and cell lines derived from both sexes respond to estrogens, anti-estrogens, and aromatase inhibitors. Therefore, therapeutic treatments that down-modulate estrogen signalling could benefit all patients, not solely women. Data are strongest for estrogen levels playing an important role in survival of women with lung cancer, and the effect of estrogen on men with lung cancer is less well studied. The relative contribution of androgen and progesterone is largely unstudied. Further understanding of the role of steroid hormones in lung cancer will provide rationales for future targeting of these pathways for therapy throughout the course of disease and possibly for lung cancer prevention. Additional understanding of the role of non-nuclear versus nuclear receptors and how to most effectively target the signaling from each cellular compartment that contributes to lung cancer progression will be important for designing effective treatments.

\section{References}

1. Jemal A, Siegel R, Ward E, Murray T, Xu J, Thun MJ. Cancer statistics, 2007. CA Cancer J Clin 2007;57:43-66. [PubMed: 17237035]

2. Muscat JE, Wynder EL. Lung cancer pathology in smokers, ex-smokers and never smokers. Cancer Lett 1995;88:1-5. [PubMed: 7850764]

3. Ryberg D, Hewer A, Phillips DH, Haugen A. Different susceptibility to smoking-induced DNA damage among male and female lung cancer patients. Cancer Res 1994;54:5801-3. [PubMed: 7954403]

4. Mollerup S, Ryberg D, Hewer A, Phillips DH, Haugen A. Sex differences in lung CYP1A1 expression and DNA adduct levels among lung cancer patients. Cancer Res 1999;59:3317-20. [PubMed: 10416585]

5. Wei Q, Cheng L, Amos CI, et al. Repair of tobacco carcinogen-induced DNA adducts and lung cancer risk: a molecular epidemiologic study. J Natl Cancer Inst 2000;92:1764-72. [PubMed: 11058619]

6. Fu JB, Severson RK, Kalemkerian GP. Lung cancer in women: analysis of the natinoal Surveillance, Epidemiology, and End Results database. Chest 2005;127:768-77. [PubMed: 15764756]

7. Parkin DM, Bray F, Ferlay J, Pisani P. Global cancer statistics, 2002. CA Cancer J Clin 2005;55:74108. [PubMed: 15761078]

8. Wakelee HA, Chang ET, Gomez SL, Keegan TH, Feskanich D, Clarke CA, et al. Lung cancer incidence in never smokers. J Clin Oncol 2007;25:481-8.

9. Albain KS, Unger JM, Gotay CC, Davies AM, Edelman M, Herbst RS, et al. Toxicity and survival by sex in patients with advanced non-small cell lung carcinoma on modern Sothwest Oncology Group (SWOG) trials. J Clin Oncol 2007;25:7549.

10. Ganti AK, Sahmoun AE, Panwalkar AW, Tendulkar KK, Potti A. Hormone replacement therapy is associated with decreased survival in women with lung cancer. J Clin Oncol 2006;24:59-63.

[PubMed: 16314616] 
11. Chlebowski RT, Schwartz AG, Wakelee H, Anderson SL, Stefanick ML, Manson JE, et al. Oestrogen plus progestin and lung cancer in postmenopausal woeman (Women's Health Initiative trial): posthoc analysis of a randomised controlled trial. Lancet. Sep 18;2009 [Epub ahead of print].

12. Ramnath N, Menezes RJ, Loewen G, Dua P, Eid F, Aikhaddo J, et al. Hormone replacement therapy as a risk factor for non-small cell lung cancer: results of case-control study. Oncology 2007;73:30510. [PubMed: 18493157]

13. Schwartz AG, Wenzlaff AS, Prysak GM, Murphy V, Cote ML, Brooks SC, et al. Reproductive factors, hormone use, estrogen receptor expression and risk of non small-cell lung cancer in women. J Clin Oncol 2007;25:5785-92. [PubMed: 18089876]

14. Fu XD, Cui YH, Lin GP, Wang TH. Non-genomic effects of 17 beta-estradiol in activation of the ERK1/ERK2 pathway induces cell proliferation through upregulation of cyclin D1 expression in bovine artery endothelial cells. Gynecol Endocrinol 2007;23:131-7. [PubMed: 17454165]

15. Belcher SM, Ma X, Le HH. Blockade of estrogen receptor signaling inhibits growth and migration of medulloblastoma. Endocrinology 2009;150:1112-21. [PubMed: 19008315]

16. Kato S, Endoh H, Masuhiro Y, Kitamoto T, Uchiyama S, Sasaki H, Masushige S, Gotoh Y, Nishida E, Kawashima H, Metzger D, Chambon P. Activation of the estrogen receptor through phosphorylation by mitogen-activated protein kinase. Science 1995;270:1491-4. [PubMed: 7491495]

17. Ishibashi H, Suzuki T, Suzuki S, Niikawa H, Lu L, Miki Y, Moriya T, Hayashi S, Handa M, Kondo $\mathrm{T}$, Sasano H. Progesterone receptor in non-small cell lung cancer--a potent prognostic factor and possible target for endocrine therapy. Cancer Res 2005;65:6450-8. [PubMed: 16024650]

18. Frasor J, Danes JM, Komm B, Chang KCN, Lyttle CR, Katzenellenbogen BS. Profiling of EstrogenUp- and Down-Regulated Gene Expression in Human Breast Cancer Cells: Insights into Gene Networks and Pathways Underlying Estrogenic Control of Proliferation and Cell Phenotype. Endocrinology 2003;144:4562-74. [PubMed: 12959972]

19. Kuiper GG, Enmark E, Pelto-Huikko M, Nilsson S, Gustafsson JA. Cloning of a novel receptor expressed in rat prostate and ovary. Proc Natl Acad Sci U S A 1996;93:5925-30. [PubMed: 8650195]

20. Mosselman S, Polman J, Dijkema R. ER beta: identification and characterization of a novel human estrogen receptor. FEBS Lett 1996;392:49-53. [PubMed: 8769313]

21. Delaunay F, Pettersson K, Tujague M, Gustafsson JA. Functional differences between the aminoterminal domains of estrogen receptors alpha and beta. Mol Pharmacol 2000;58:584-90. [PubMed: 10953052]

22. Lau KM, LaSpina M, Long J, Ho SM. Expression of estrogen receptor (ER)-alpha and ER-beta in normal and malignant prostatic epithelial cells: regulation by methylation and involvement in growth regulation. Cancer Res 2000;60:3175-82. [PubMed: 10866308]

23. Brzozowski AM, Pike AC, Dauter Z, et al. Molecular basis of agonism and antagonism in the oestrogen receptor. Nature 1997;389:753-8. [PubMed: 9338790]

24. Shiau AK, Barstad D, Loria PM, et al. The structural basis of estrogen receptor/coactivator recognition and the antagonism of this interaction by tamoxifen. Cell 1998;95:927-37. [PubMed: 9875847]

25. Stabile LP, Davis AL, Gubish CT, Hopkins TM, Luketich JD, Christie N, Finkelstein S, Siegfried JM. Human non-small cell lung tumors and cells derived from normal lung express both estrogen receptor alpha and beta and show biological responses to estrogen. Cancer Res 2002;62:2141-50. [PubMed: 11929836]

26. Hershberger PA, Stabile LP, Kanterewicz B, et al. Estrogen receptor beta (ERbeta) subtype-specific ligands increase transcription, p44/p42 mitogen activated protein kinase (MAPK) activation and growth in human non-small cell lung cancer cells. J Steroid Biochem Mol Biol. 2009

27. Ciana P, DiLuccio G, Belcredito S, Pollio G, Vegeto E, Tatangelo L, Tiveron C, Maggi A. Engineering of a Mouse for the in Vivo Profiling of Estrogen Receptor Activity. Molecular Endocrinology 2001;15:1104-13. [PubMed: 11435611]

28. Lemmen JG, Arends RJ, van Boxtel AL, van der Saag PT, van der Burg B. Tissue- and time-dependent estrogen receptor activation in estrogen reporter mice. J Mol Endocrinol 2004;32:689-701. [PubMed: 15171709] 
29. Patrone C, Cassel TN, Pettersson K, Piao Y-S, Cheng G, Ciana P, Maggi A, Warner M, Gustafsson J-A, Nord M. Regulation of Postnatal Lung Development and Homeostasis by Estrogen Receptor $\beta$. Molecular and Cellular Biology 2003;23:8542-52. [PubMed: 14612399]

30. Morani A, Barros RP, Imamov O, et al. Lung dysfunction causes systemic hypoxia in estrogen receptor beta knockout (ERbeta-/-) mice. Proc Natl Acad Sci U S A 2006;103:7165-9. [PubMed: 16636272]

31. Kawai H, Ishii A, Washiya K, Konno T, Kon H, Yamaya C, Ono I, Ogawa J. Combined overexpression of EGFR and estrogen receptor alpha correlates with a poor outcome in lung cancer. Anticancer Res 2005;25:4693-98. [PubMed: 16334162]

32. Wu CT, Chang YL, Shih JY, Lee YC. The significance of estrogen receptor beta in 301 surgically treated non-small cell lung cancers. J Thorac Cardiovasc Surg 2005;130:979-86. [PubMed: 16214508]

33. Schwartz AG, Prysak GM, Murphy V, Lonardo F, Pass H, Schwartz J, Brooks S. Nuclear estrogen receptor beta in lung cancer: expression and survival differences by sex. Clin Cancer Res 2005;11:7280-7. [PubMed: 16243798]

34. Skov BG, Fischer BM, Pappot H. Oestrogen receptor b over expression in males with non-small cell lung cancer is associated with better survival. Lung Cancer 2008;59:88-94. [PubMed: 17905466]

35. Osborne CK, Yochmowitz MG, Knight WA 3rd, McGuire WL. The value of estrogen and progesterone receptors in the treatment of breast cancer. Cancer 1980;46:2884-8. [PubMed: 7448733]

36. Thorpe SM, Rose C, Rasmussen BB, Mouridsen HT, Bayer T, Keiding N. Prognostic value of steroid hormone receptors: multivariate analysis of systemically untreated patients with node negative primary breast cancer. Cancer Res 1987;47:6126-33. [PubMed: 3664512]

37. Maggiolini M, Picard D. The unfolding stories of GPR30, a new membrane-bound estrogen receptor. J Endocrinol. Sep 18;2009 [Epub ahead of print].

38. Pietras RJ, Marquez DC, Chen HW, Tsai E, Weinberg O, Fishbein M. Estrogen and growth factor receptor interactions in human breast and non-small cell lung cancer cells. Steroids 2005;70:372-81. [PubMed: 15862820]

39. Stabile LP, Lyker JS, Gubish CT, Zhang W, Grandis JR, Siegfried JM. Combined Targeting of the Estrogen Receptor and the Epidermal Growth Factor Receptor in Non-Small Cell Lung Cancer Shows Enhanced Anti-Proliferative Effects. Cancer Research 2005;65:1459-70. [PubMed: 15735034]

40. Zhang G, Liu X, Farkas AM, et al. Estrogen receptor beta functions through nongenomic mechanisms in lung cancer cells. Mol Endocrinol 2009;23:146-56. [PubMed: 19106194]

41. Marquez-Garban DC, Chen HW, Fishbein MC, Goodglick L, Pietras RJ. Estrogen receptor signaling pathways in human non-small cell lung cancer. Steroids 2007;72:135-43. [PubMed: 17276470]

42. Traynor AM, Schiller JH, Stabile LP, Kolesar JM, Belani CP, Hoang T, Dubey S, Eickhoff J, Larson ML, Marcotte SM, Siegfried JM. Combination treatment with gefitinib and fulvestrant for postmenopausal women with advanced non-small cell lung cancer. Lung Cancer 2009;64:51-9. [PubMed: 18701186]

43. Garon EB, Sadeghi S, Kabbinavar FF, Reckamp KL, Marquez-Garban DC, Stabile LP, et al. Interim safety analysis of a phase II study of erlotinib (E) alone or combined with fulvestrant $(\mathrm{F})$ in previously treated patients with advanced non-small cell lung cancer (NSCLC). J Clin Oncol (Meeting abstracts) 2008;26:19091.

44. Pedram A, Razandi M, Wallace DC, Levin ER. Functional estrogen receptors in the mitochondria of breast cancer cells. Mol Biol Cell 2006;17:2125-37. [PubMed: 16495339]

45. Mattingly KA, Ivanova MM, Riggs KA, Wickramasinghe NS, Barch MJ, Klinge CM. Estradiol stimulates transcription of nuclear respiratory factor-1 and increases mitochondrial biogenesis. Mol Endocrinol 2008;22:609-22. [PubMed: 18048642]

46. Yang SH, Sarkar SN, Liu R, et al. Estrogen receptor beta as a mitochondrial vulnerability factor. J Biol Chem 2009;284:9540-8. [PubMed: 19189968]

47. Chen JQ, Eshete M, Alworth WL, Yager JD. Binding of MCF-7 cell mitochondrial proteins and recombinant human estrogen receptors alpha and beta to human mitochondrial DNA estrogen response elements. J Cell Biochem 2004;93:358-73. [PubMed: 15368362]

48. Klinge CM. Estrogenic control of mitochondrial function and biogenesis. J Cell Biochem 2008;105:1342-51. [PubMed: 18846505] 
49. Simpkins JW, Yang SH, Sarkar SN, Pearce V. Estrogen actions on mitochondria--physiological and pathological implications. Mol Cell Endocrinol 2008;290:51-9. [PubMed: 18571833]

50. Virbasius CA, Virbasius JV, Scarpulla RC. NRF-1, an activator involved in nuclear-mitochondrial interactions, utilizes a new DNA-binding domain conserved in a family of developmental regulators. Genes Dev 1993;7:2431-45. [PubMed: 8253388]

51. Yang SH, Liu R, Perez EJ, et al. Mitochondrial localization of estrogen receptor beta. Proc Natl Acad Sci U S A 2004;101:4130-5. [PubMed: 15024130]

52. Chen JQ, Delannoy M, Cooke C, Yager JD. Mitochondrial localization of ERalpha and ERbeta in human MCF7 cells. Am J Physiol Endocrinol Metab 2004;286:E1011-22. [PubMed: 14736707]

53. Milanesi L, Vasconsuelo A, de Boland AR, Boland R. Expression and subcellular distribution of native estrogen receptor beta in murine $\mathrm{C} 2 \mathrm{C} 12$ cells and skeletal muscle tissue. Steroids 2009;74:489-97. [PubMed: 19428437]

54. Cammarata PR, Chu S, Moor A, Wang Z, Yang SH, Simpkins JW. Subcellular distribution of native estrogen receptor alpha and beta subtypes in cultured human lens epithelial cells. Exp Eye Res 2004;78:861-71. [PubMed: 15037120]

55. Hammoud Z, Tan B, Badve S, Bigsby RM. Estrogen promotes tumor progression in a genetically defined mouse model of lung adenocarcinoma. Endocr Relat Cancer 2008;15:475-83. [PubMed: 18509000]

56. Hershberger PA, Vasquez AC, Kanterewicz B, Land S, Siegfried JM, Nichols M. Regulation of endogenous gene expression in human non-small cell lung cancer cells by estrogen receptor ligands. Cancer Res 2005;65:1598-605. [PubMed: 15735050]

57. Jarzynka MJ, Guo P, Bar-Joseph I, Hu B, Cheng SY. Estradiol and nicotine exposure enhances A549 bronchioloalveolar carcinoma xenograft growth in mice through the stimulation of angiogenesis. Int J Oncol 2006;28:337-44. [PubMed: 16391787]

58. Weinberg OK, Marquez-Garban DC, Fishbein MC, Goodglick L, Garban HJ, Dubinett SM, Pietras RJ. Aromatase inhibitors in human lung cancer therapy. Cancer Res 2005;65:11287-91. [PubMed: 16357134]

59. Martel C, Melner MH, Gagné D, Simard J, Labrie F. Widespread tissue distribution of steroid sulfatase, 3 beta-hydroxysteroid dehydrogenase/delta 5-delta 4 isomerase ( 3 beta-HSD), 17 betaHSD 5 alpha-reductase and aromatase activities in the rhesus monkey. Mol Cell Endocrinol 1994;104:103-11. [PubMed: 7821701]

60. Price T, Aitken J, Simpson ER. Relative expression of aromatase cytochrome P450 in human fetal tissues as determined by competitive polymerase chain reactionamplification. J Clin Endocrinol Metab 1992;74:879-83. [PubMed: 1548354]

61. Marquez-Garban DC, Chen HW, Goodglick L, Fishbein MC, Pietras RJ. Targeting aromatase and estrogen signaling in human non-small cell lung cancer. Ann N Y Acad Sci 2009;1155:194-205. [PubMed: 19250205]

62. Coombes RC, Hall E, Gibson LJ, Paridaens R, Jassem J, Delozier T, Jones SE, Alvarez I, Bertelli G, Ortmann O, Coates AS, Bajetta E, Dodwell D, Coleman RE, Fallowfield LJ, Mickiewicz E, Andersen J, Lønning PE, Cocconi G, Stewart A, Stuart N, Snowdon CF, Carpentieri M, Massimini G, Bliss JM, van de Velde C, Intergroup Exemestane Study. A randomized trial of exemestane after two to three years of tamoxifen therapy in postmenopausal women with primary breast cancer. $\mathrm{N}$ Engl J Med 2004;35011:1081-92. [PubMed: 15014181]

63. Mah V, Seligson DB, Li A, et al. Aromatase expression predicts survival in women with early-stage non small cell lung cancer. Cancer Res 2007;67:10484-90. [PubMed: 17974992]

64. Buzdar AU, Coombes RC, Goss PE, Winer EP. Summary of aromatase inhibitor clinical trials in postmenopausal women with early breast cancer. Cancer 2008;112:700-9. [PubMed: 18072256]

65. Eisen A, Trudeau M, Shelley W, Messersmith H, Pritchard KI. Aromatase inhibitors in adjuvant therapy for hormone receptor positive breast cancer: a systematic review. Cancer Treat Rev 2008;34:157-74. [PubMed: 18164821]

66. Wang Y, Brown M. Molecular Determinants for the Tissue Specificity of SERMs. Science 2002;295:2465-8. [PubMed: 11923541]

67. Fisher B, Costantino JP, Wickerham DL, Redmond CK, Kavanah M, Cronin WM, Vogel V, Robidoux A, Dimitrov N, Atkins J, Daly M, Wieand S, Tan-Chiu E, Ford L, Wolmark N. Tamoxifen for 
prevention of breast cancer: report of the National Surgical Adjuvant Breast and Bowel Project P-1 Study. J Natl Cancer Inst 1998;90:1371-88. [PubMed: 9747868]

68. Niikawa H, Suzuki T, Miki Y, et al. Intratumoral estrogens and estrogen receptors in human nonsmall cell lung carcinoma. Clin Cancer Res 2008;14:4417-26. [PubMed: 18579664]

69. Wang P-H, Wang H-C, Tsai C-C. Estogen replacement in female lung cancer during gefitinib therapy. Jpn J Clin Oncol 2009;10 


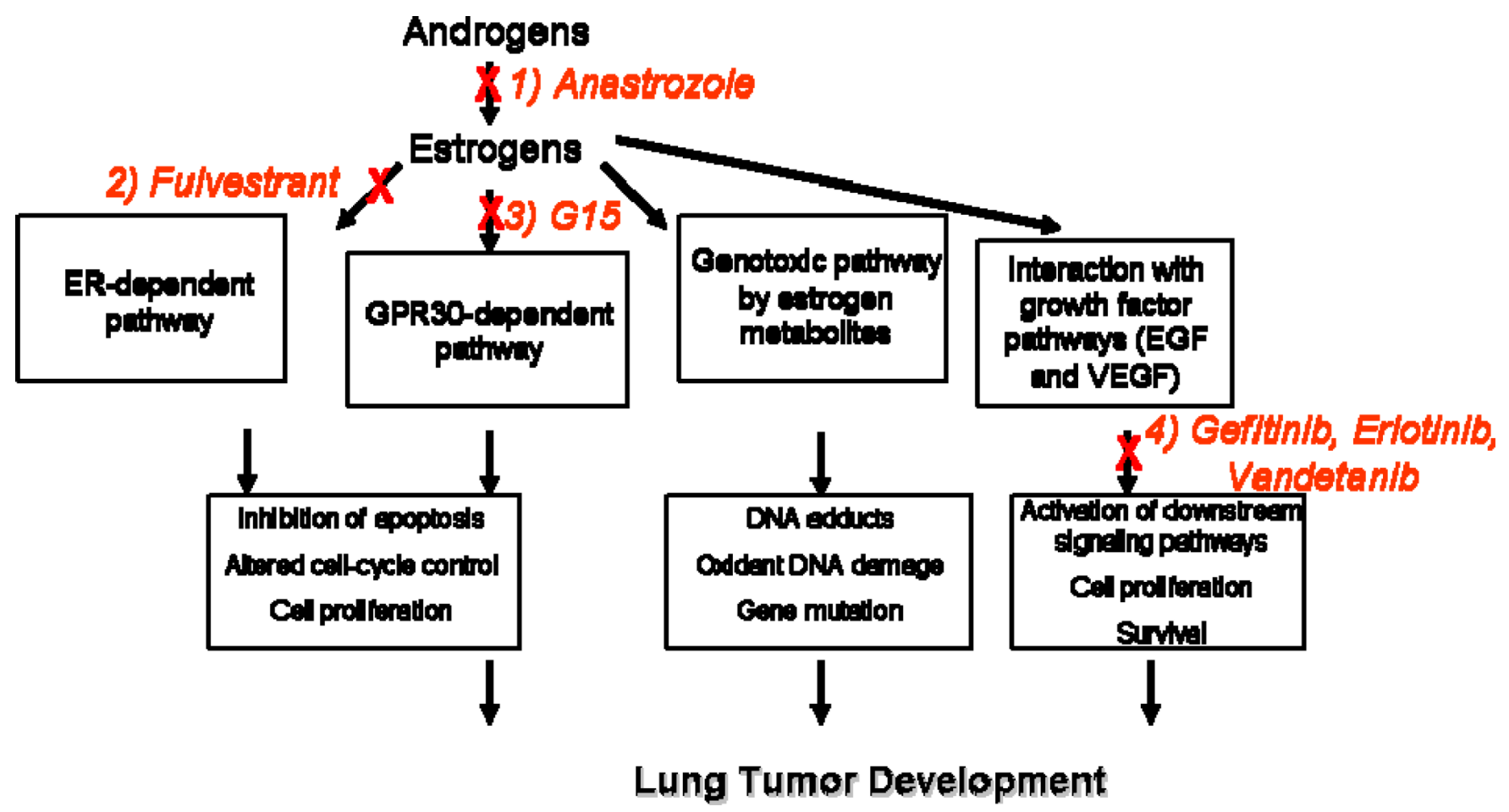

Figure 1.

Available strategies to target the estrogen signaling pathway for lung cancer include 1) inhibition of the final step in the synthesis of estrogen, by inhibiting the enzyme aromatase with the inhibitor anastrozole; 2) down-regulation of classical ERs using the pure antiestrogen fulvestrant; 3) inhibition of GPR30-dependent signaling through the newly identified GPR30 antagonist, G15; 4) targeting the growth factor pathways that are activated by estrogens, mainly the EGF and VEGF pathways using the drugs gefitinib, erlotinib or vandetanib. These strategies can be used alone or in combination. 